\title{
Remembering the Past, Cultivating a Character: Memory and the Formation of Daniel in the Aramaic Pseudo-Daniel Texts (4Q243-244; 4Q245)
}

\author{
Andrew B. Perrin
}

Pseudo-Daniel and Intersections in the Aramaic Corpus*

The texts collected under the Pseudo-Daniel rubric are an intriguing item in the Aramaic Dead Sea Scrolls as they bridge two predominant foci observed for the broader Aramaic corpus. On the one hand, the texts are associated with life in the exilic diaspora by way of attribution to a "Daniel" and mention of political figures and eras associated with prevailing empires of the recent past. On the other hand, aspects of their fragmentary content are anchored in the antediluvian and ancestral ages. The scribes behind these texts make regular nods to the flood, the tower of Babel, the exodus, the patriarchs, and both royal and priestly genealogies.

While this content invites many questions, in this essay I will explore but two. First, how can a reading informed by insights from memory studies advance our understanding of the situation of the Pseudo-Daniel materials at an apparent nexus of the two main narrative settings of the Aramaic corpus? Second, how did this new narrative and thematic backdrop at once enhance the emerging persona of Daniel as a literary character as well as enable the creator of these writings to redeploy this Daniel to speak into a broader set of topics? Qumran Collection

Memories are not static items tucked away in a cognitive time-capsule. They are created, changed, even updated when accessed. Pioneered in the cognitive sciences and sociology, memory studies has become a diverse and diffuse field both testing and providing tools to explore the relation between past events and their subsequent representations, recapitulations, and recreations. These

* Research for this article was supported by a Social Sciences and Humanities Research Council Insight Grant. 
tools may apply to different domains, from individual to social and collective memory. ${ }^{1}$

Olick and Robbins' essay remains the essential primer on the history of research on memory. ${ }^{2}$ They commented that "memory is not an unchanging vessel for carrying the past into the present; memory is a process, not a thing, and it works differently at different points in time." ${ }^{3}$ In some sense, memories deal in inherited currency but their current expressions are recreated in view of the ever-passing moment of events, individuals, and experiences. Memory is also orientational and axial insofar as it serves the purposes of identity formation and maintenance in light of both a multi-dimensional past and a present context that is equally dynamic. Representations of the past-whether individual or collective, penned or performed - are at once formed within and formed for collectives.

Schwartz's concise explanation of what constitutes social memory is a helpful departure point. "Memory is a fundamental property of the mind, an indispensable component of culture, and an essential aspect of tradition. Although individuals alone possess the capacity to remember the past, they never do so singly; they do so with and against others situated in different groups and through the knowledge and symbols that predecessors and contemporaries transmit to them."4 Schwartz further observed that "[m]edia are memory's vehicles," with media being understood in the broadest possible sense. ${ }^{5}$ If media are the vehicles of memory, then the Qumran library is a veritable parking lot of memories inscribed in text form.

Deploying terminology of a "textual community" coined by Brian Stock, Jan Assmann once briefly characterized the Qumran library and community in such terms. He suggested that, like the Nag Hammadi codices, the Judaean Desert finds "give us an insight into the vestiges of the libraries that were used as a foundation by such textual communities. Despite their fragmentary

1 In their programmatic essay on the emergence of memory studies, Roediger and Wertsch described the field as "a huge tent in which scholars from many perspectives and fields can find a home, using their quite disparate methods and means of inquiry," yet also underscored the need for increased methodological precision moving forward (Henry L. Roediger, III and James V. Wertsch, "Creating a New Discipline of Memory Studies," Memory Studies 1 [2008]: $\left.9^{-22}[12]\right)$.

2 Jeffrey K. Olick and Joyce Robbins, "Social Memory Studies: From 'Collective Memory' to the Historical Sociology of Mnemonic Practices," Annual Review of Sociology 24 (1998): 105-40.

3 Olick and Robbins, "Social Memory Studies," 122.

4 Barry Schwartz, "Where There's Smoke, There's Fire: Memory and History," in Memory and Identity in Ancient Judaism and Early Christianity: A Conversation with Barry Schwartz, ed. Tom Thatcher, SemeiaSt 78 (Atlanta: SBL Press, 2014), 7-37 (9).

5 Schwartz, "Where There's Smoke, There's Fire," 10. 
condition they enable us to infer that, unlike modern libraries, they did not aim at the greatest possible variety and completeness. Instead, they confined themselves to the literature that the community deemed authoritative." 6 Stock's earlier articulation of this idea underscored the role that we might call the tradent in the formation of textual communities. He wrote, "[w] hat was essential to a textual community was not a written version of a text, although that was sometimes present, but an individual, who, having mastered it, then utilized it for reforming a group's thought and action." ${ }^{7}$

Transposing this concept to the Qumran community requires considering the creative activity of the scribes in the presentation of memories. In doing this, the motivations for scribal intervention - that is, the ways scribes engaged and extended the traditions they handled - take on new significance. One cross-section of the Qumran collection that invites this type of exploration are those writings often described as "rewritten bible/scripture," "parabiblical/scriptural," and "paratextual." 8 George Brooke recently began to bridge the gap between our understanding of scribal memory and the cultivation of traditions in our so-called rewritten texts. He wrote:

[A]n individual mind, what it remembers, how it articulates and rearticulates what it remembers, how it functions, needs to be considered as part of the process of the transmission (and development) of authoritative traditions ... They [instances of scribal intervention] might also indicate how an author considers his standing within a particular historical perspective and attempt to manipulate an audience towards a similar standing. The motivations for adjusting the received traditions in the rewriting process are ideological in one way or another. ${ }^{9}$

6 Jan Assmann, Religion and Cultural Memory: Ten Studies, trans. Rodney Livingstone (Stanford, CA: Stanford University Press, 2006), 73. See also Jan Assmann, Moses the Egyptian: The Memory of Egypt in Western Monotheism (Cambridge, MA: Harvard University Press, 1998).

7 Brian Stock, The Implications of Literacy: Written Language and Models of Interpretation in the Eleventh and Twelfth Centuries (Princeton: Princeton University Press, 1983), 90.

8 For a survey of texts and the thorny theoretical and terminological issues related to such materials, see Daniel A. Machiela, "Once More, with Feeling: Rewritten Scripture in Ancient Judaism-A Review of Recent Developments," JJs 61 (2010): 308-20; Molly M. Zahn, "Genre and Rewritten Scripture: A Reassessment," JBL 131 (2012): 271-88; and Jonathan G. Campbell, "Rewritten Bible: A Terminological Reassessment," in Rewritten Bible after Fifty Years: Texts, Terms, or Techniques? A Last Dialogue with Geza Vermes, ed. József Zsengellér, JsJs 166 (Leiden: Brill, 2014), 49-81.

9 George J. Brooke, "Memory, Cultural Memory and Rewriting Scripture," in Rewritten Bible after Fifty Years: Texts, Terms, or Techniques? A Last Dialogue with Geza Vermes, ed. József Zsengellér, JSJs 166 (Leiden: Brill, 2014), 119-36 (122). 
From here, Brooke proposed four "somewhat overlapping dimensions or processes" that relate to aspects of scribal memory involved in rewriting traditions: (i) embellishment and institutionalization, (ii) distortion and obligation, (iii) invention and organization, and (iv) forgetting and the capacity for reconstruction..$^{10}$ As rightly noted by Brooke, considering such dimensions of memories embedded in texts is not concerned with recovering or reconstructing the historical past as it really happened; rather, "we are concerned to notice how a community's memory works to handle the traditions it receives in recognizable ways by providing implicit commentary as cultural memories are changed and adjusted."11 Brooke's case studies focused on rewritten texts in a close degree to, and discernible dependence upon, Pentateuchal tradition (i.e., Jubilees, Reworked Pentateuch, Genesis Apocryphon, Temple Scroll, selections from Josephus' Antiquities). Yet, how should we approach cases where the antecedent tradition is less stable and discernable, demonstrably authoritative, or to state the obvious, a more recent creation of scribal culture? As would be the case with Daniel in the mid-Second Temple period.

On the one hand, Brooke's model for exploring the intersection of memory and rewriting could be applied to Josephus' selective and strategic rendition of Daniel in Antiquities 10.186-12.322. Josephus wends his way through the antecedent tradition all the while negotiating his present political context and ancestral ties. In watching Josephus work, however, it is clear that he is working with a version of what we eventually call "biblical" Daniel. ${ }^{12}$ Therefore, the Daniel we meet in Josephus is to be understood as the same character from the book of his namesake, albeit a Daniel remodeled through memory.

On the other hand, unlike Josephus, the Danielic texts among the Qumran Aramaic corpus do not seem to be crafted upon a clear antecedent, a "book" of Daniel. Rather, they are oriented around a figure: Daniel. For this reason, I am not inclined to explore the topic of memory in the early Danielic tradition in terms of a genealogy of developing written traditions in degrees of succession from some postulated textual ancestor. A more favorable approach-and one that takes the cautions of canonical anachronism seriously—works toward accounting for the scope of dynamic Danielic traditions on the basis of their common core association with a shared persona. ${ }^{13}$

10 Brooke, "Memory, Cultural Memory and Rewriting Scripture," 128-31.

11 Brooke, "Memory, Cultural Memory and Rewriting Scripture," 128.

12 For preliminary discussions of Josephus' interaction with Daniel traditions, see Frederick F. Bruce, "Josephus and Daniel," in A Mind for What Matters: Collected Essays of F. F. Bruce (Grand Rapids, MI: Eerdmans, 199o), 19-31; and Géza Vermes, "Josephus' Treatment of the Book of Daniel," JJS 42 (1991): 149-66.

13 See especially Hindy Najman, Seconding Sinai: The Development of Mosaic Discourse in Second Temple Judaism, JSJs 77 (Leiden: Brill, 2003). 
The materials collected under the title Pseudo-Daniel relate to fragments of three known Aramaic manuscripts recovered from Qumran Cave 4. 4QPseudo-Daniel ${ }^{\mathrm{a}-\mathrm{b}}$ (4Q243-4Q244) benefit from modest textual overlap confirming they are copies of the same work. 4 QPseudo-Danielc ${ }^{\mathrm{C}}(4 \mathrm{Q} 245)$ is highly fragmentary and does not overlap with surviving content of the preceding pair. It cannot be determined whether or not this is a third copy of the same ancient work. One potentially significant thematic similarity suggesting a degree of relation is the fragmentary references to the priestly forefathers in $4 \mathrm{Q}_{243} 28$ and the more complete list in $4 \mathrm{Q}_{245} 1 \mathrm{i}^{14}$ What is common to all three manuscripts, however, is their explicit association with our leading actor, Daniel. ${ }^{15}$ This association locates the manuscripts in a common tradition regardless of their textual status. Pseudo-Daniel indeed exhibits some shared themes and figures with the biblical book. However, the nature of the relation between these texts or reliance upon a common shared tradition is not always clear. ${ }^{16}$

The dates of the manuscripts are nearly coterminous with "biblical" Daniel. As suggested by Collins and Flint, the manuscripts seem to have been penned in Herodian hands of the late first century вСE. ${ }^{17}$ Based on internal references, formal quality, and ideological aspects, Collins and Flint concluded " $t$ t]he most likely time of composition is somewhere between the beginning of the second century в СЕ and the coming of Pompey" (са. mid-second century вСЕ to 63 ВСе ). ${ }^{18}$ If this range is accepted even provisionally, it is entirely possible that there is nothing "pseudo" about Pseudo-Daniel at all. Rather, these Aramaic

14 As noted by Collins and Flint, "If the text is correctly read so that it [4Q243 28] refers to Qahat, Phineas, and his son Abishua, this fragment provides possible evidence for a relationship between 4Q243 and 4Q245" (John J. Collins and Peter W. Flint, "Pseudo-Daniel," in Qumran Cave 4.XVII: Parabiblical Texts, Part 3, ed. George J. Brooke et al., DJD 22 [Oxford: Clarendon Press, 1996], 95-164 [116]).

15 4Q243 1 1; 2 1; 5 1; 6 3; 4Q244 4 2; 4Q245 1 i 3.

16 As Collins noted, "It is at least clear that Pseudo-Daniel is not closely modelled on the biblical book, but goes its own way, by having Daniel expound the full sweep of Israelite history. Whether it depended on the biblical book at all no longer seems as clear as it did when we relied on Milik's construction" (John J. Collins, "Pseudo-Daniel Revisited," RevQ 17 [1996]: 111-35 [118]). To date, DiTommaso has undertaken the most detailed study of the thematic and theological similarities and differences between the two works (Lorenzo DiTommaso, “4QPseudo-Daniel ${ }^{a-b}\left(4 \mathrm{Q} 243^{-244)}\right.$ and the Book of Daniel," DSD 12 [2005]: 101-33).

17 For palaeographical descriptions and manuscript profiles, see Collins and Flint, DJD 22:97, 122, 154 .

18 Collins and Flint, DJD 22:97. 
writings emerged at a time close to or contemporary with the development of Dan 1-12 in the mid-16os BCE.

While the question of the relation of the materials in $4 \mathrm{Q}_{243}-4 \mathrm{Q} 244$ with those of $4 \mathrm{Q}_{245}$ is vexing, since my aim is to work towards a model that accounts for the robust tradition oriented around the figure of Daniel, I will draw on these fragments as a group to ascertain what portrait of Daniel results. With vitals of the Pseudo-Daniel fragments now taken, I will now tour through key memories included in these materials and ask how different episodes or eras contribute to the development of our recently recovered Daniel.

\section{Redrawing Figures from International Lore in Early Jewish Aramaic Traditions: Dan'el, Ahiqar, Nabonidus, and Gilgamesh}

It is widely recognized that at least part of the answer to the question "Who is Daniel?" is to be found in the ancient Near Eastern Dānïilu in the Aqhat Epic of Ugarit (ca. 14th-13th century BCE).${ }^{19}$ While this tradition predates our Second Temple Jewish traditions by a margin, references to "Danel" (דנאל) in Ezek 14:14, 14:20, and 28:3 as a figure receiving honorable mention alongside Noah and Job-who also have their own ancient Near Eastern analogues-likely represents a bridge over which the sagely figure of the Aqhat Epic entered Israelite culture and tradition. Jub. 4:20 also includes an intriguing reference to one "Dan'el." Here the figure is a near relation to Enoch. ${ }^{20}$ While all of these references present their own interpretive challenges, they suggest that by the time we meet Daniel in our Aramaic traditions of the mid-Second Temple period, a preliminary profile for him already existed in Jewish memory that was associated with sagely expertise, visionary experience, and key antediluvian ancestors.

While the recognition that the character of Daniel has some ancient Near Eastern lineage is not new, considering this development in the context of the Qumran Aramaic texts is. What we find in this corpus is something of a trend for recasting famed figures of ancient Near Eastern lore in Jewish traditions of the Second Temple period. There are at least three texts that participate in this creative approach to characterization.

19 For an introduction and translation to this text, see "The 'Aqhatu Legend (1.103)," trans. Dennis Pardee ( $\left.\cos 1.103: 343^{-56}\right)$.

20 Compare also the parallel of 1 En. 85:3. Note also the appearance of a "Daniel" (דניאל) among the list of the wayward watchers at 1 En. 6:7 (4Q201 1 iii 8; 4Q204 1 ii 26). 
First, the writer of Tobit positions Ahiqar as a high-courtier in the service of both Sennacherib and Esarhaddon yet supplies him with an unmistakable Israelite heritage: he is claimed as Tobit's own nephew of Napthalite descent (Tob 1:21; 2:10; 11:18; 14:10). ${ }^{21}$ Second, the Aramaic Book of Giants cast "Gilgamesh" as one of the barbarous and blood-thirsty Nephilim (4Q530 2 ii + 6-12(?) 2; 4Q532 22 12). ${ }^{22}$ In this instance, the jab at the hero of the Babylonian flood myth is that Gilgamesh was nothing more than an ill-fated accident of an angelic-human one-night stand. Third, the scribe of the Prayer of Nabonidus adopted and adapted the known political figure of "Nabonidus," yet represented him in an episode underscoring his submission to the God of Israel. ${ }^{23}$

Like Danel, the figures of Ahiqar, Gilgamesh, and Nabonidus are ubiquitous across ancient Near Eastern traditions yet through scribal innovation and memory they find themselves making cameos in Second Temple Jewish Aramaic texts. In this process, none of the aforementioned characters are cast out of whole cloth. The participants in the Daniel tradition in the mid-Second Temple period cultivated a character in new narrative settings but did so on the basis of a figure already existing in some outline in wider cultural lore and benefitting from a place in the more immediate memory of Israelite tradition. ${ }^{24}$

Retrospective References and Prospective Genealogies: Patriarchs, Priests, and Kings

In the biblical book, Daniel's identity as an Israelite is established in the introductory Hebrew chapters and he is momentarily associated with figures and

21 As Moore observed, "[t]he author of Tobit either modeled his Ahiqar after it [the Ahiqar tale] or, more likely, assumed his reader's familiarity with it” (Carey A. Moore, Tobit, AB [New Haven: Yale University Press, 1996], 12).

22 On this guest appearance of Gilgamesh, see Matthew J. Goff, "Gilgamesh the Giant: The Qumran Book of Giants' Appropriation of Gilgamesh Motifs," DSD 16 (2009): 221-53; and Ida Fröhlich, "Babyloniaca from Qumran-Mesopotamian Lore in Qumran Aramaic Texts," in Studies in Economic and Social History of the Ancient Near East in Memory of Péter Vargyas, ed. Zoltán Csabai, Ancient Near Eastern and Mediterranean Studies 2 (Budapest: Hungarian Society for Ancient Studies, 2014), 577-6o1.

23 On this, see Carol A. Newsom, "Why Nabonidus? Excavating Traditions from Qumran, the Hebrew Bible, and Neo-Babylonian Sources," in The Dead Sea Scrolls: Transmission of Traditions and Production of Texts, ed. Sarianna Metso, Hindy Najman, and Eileen Schuller, STDJ 92 (Leiden: Brill, 2010), 57-79.

24 Daniel of the "biblical" book also bears noteworthy resemblance to Joseph. On this, see Lee W. Humphreys, "A Life-Style for the Diaspora: A Study of the Tales of Esther and Daniel," JBL 92 (1973): 211-23; and, more recently, Michael Segal, Dreams, Riddles, and Visions: Textual, Contextual, and Intertextual Approaches to the Book of Daniel, BZAW 455 (Berlin: de Gruyter, 2016), 48-51. 
experiences of the ancestral past in the penitential prayer of Dan 9, which mentions Moses and alludes to the exodus (Dan 9:11, 13, 15). The Aramaic unit of Dan 2-7, however, has little recourse to such traditions or personages. Daniel's identity is largely cultivated in the space of the memory of exile looking forward. Pseudo-Daniel, however, draws upon a deeper and more diverse range of ancestral actors embedded in Israel's story remembered. While Daniel is a latecomer to Israelite tradition, the surviving fragments of 4 Q $243-244$ and 4Q245 position him against the backdrop of its earliest foundational characters and essential institutions from both the patriarchal past and Israelite history proper.

\subsection{References to Antediluvian Figures from Genesis}

The fortuitous yet frustrating surviving text of 4 Q243 91 reads simply the words "to Enoch" (לחנוך.). cates some association with the memory of the liminal figure of Gen 5:18-24 who becomes a larger than life personage in Second Temple period Aramaic literature. A second anchor on the other side of the deluge is found in 4 Q244 83 , which names "Noah" (נ่) in some post-flood description. It is also possible that the reference to "the Chaldeans" (כשדיא) in 4Q243 72 relates to an Abrahamic tradition.

By virtue of importing named figures from the antediluvian and patriarchal past into the Aramaic text, the Daniel we meet in Pseudo-Daniel is not vaguely associated with "our ancestors" as is his counterpart in Aramaic Dan 2-7. On the contrary, naming Enoch, Noah, and perhaps others, anchors this budding Second Temple tradition in the ancestral past and associates this relatively new exilic character of Daniel with memories of essential figures from the foundational narratives of Genesis. Establishing an association between Daniel and a longer heritage of ancestors, however, is achieved most in the genealogical content of the Pseudo-Daniel fragments.

\subsection{Coordinating the Past along Genealogical Lines}

Beneath their sleep-inducing exterior, genealogies are an essential medium for selecting, ordering, and posturing a chronology of generations past in view of present individual or communal institutions and identity. Their strategic formulation and presentation is where history (in the broadest sense of antecedent events and individuals) becomes heritage, that is, the curated memory of a group. As vehicles of memory, genealogies relate to both identity and authority.

25 Unless otherwise noted, all transcriptions and translations are based on Collins and Flint, DJD 22. 
More than listing figures from the past, the genealogy in $4 \mathrm{Q}_{245}$ focuses on figureheads associated with two iconic institutions in Israelite memory: the priesthood and the monarchy. While I will not undertake a comprehensive profile of the entire genealogy, some preliminary remarks on the more salient features of the list will help direct our interest to the genealogy as a mechanism of memory and tool for characterization. ${ }^{26}$

\subsection{Merging Memories of Diverse Priestly Origins with Ex Eventu Estimations of Second Temple Priesthoods}

As noted in the introduction to Pseudo-Daniel above, $4 \mathrm{Q}_{243} 28$ includes the first glimpse of genealogical material in the texts. If the proposed reconstructions of Collins and Flint are accepted, this fragment may include references to at least three priestly figures.

1. ]el and Qa[hat (ואל וקס)

2. Phineha]s, Abish[ua (פינח]ס אביש[וע)

3. ]...[ (०००[ ] ש ש)

If these partially reconstructed readings are correct, it may provide a critical link to either traditional or textual affiliation with the more expansive genealogical list of $4 \mathrm{Q}_{245} 1 \mathrm{i}$. The original text and translation of this fragment are as follows:

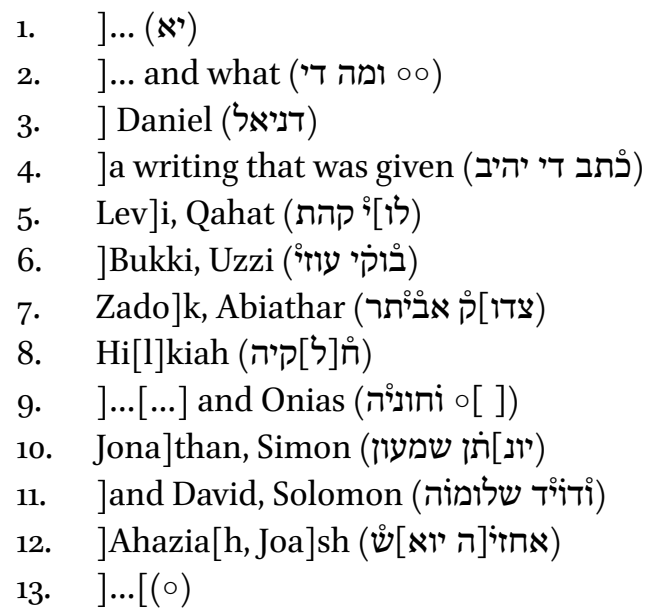

When anchoring a new tradition in the past, founding figures matter. The above fragment traces the priestly genealogy through generations beginning with its earliest representatives. 4Q 245 i i 5 commences with a likely reference to "Lev]i" followed immediately by the extant name "Qahat." Incidentally, the

26 For an attempt at a comprehensive reconstruction, see Michael O. Wise, "4Q245 (PsDanc ar) and the High Priesthood of Judas Maccabaeus," DSD 12 (2005): 313-62. 
memories of these figures were the subject of extensive scribal creativity in the Aramaic Levi Document (1Q21, 4Q213, 4Q213a, 4Q213b, 4Q214, 4Q214a, 4Q214b) and Testament of Qahat $\left(4 \mathrm{Q}_{542}\right)$ at Qumran. Unfortunately, the line of text crumbles after the mention of Qahat in $4 \mathrm{Q}_{245} 1$ i 5 . Given the context, it would be reasonable to posit that "Amram" followed thereafter, who likewise enjoyed an existence in Second Temple memory at Qumran in the Aramaic Visions of Amram (4Q543-547). Not unlike the focus of this fragment of Pseudo-Daniel, these Aramaic priestly pseudepigrapha exhibit emphatic interests in tracing the priestly line and genealogy from its inception. ${ }^{27}$

Unlike the Levi, Qahat, and Amram texts, however, Pseudo-Daniel extends to include future generations of Israel's priests beyond those remembered in Genesis. The figures "Bukki" and "Uzzi" found in line 6 of the genealogy are remembered by the Chronicler for their Aaronide lineage (1 Chr 6:3-5). The likely pairing of "Zadok" and "Abiathar" in line 7 presents the frontrunners of two priestly lines that rise to prominence and eventual contest in the early monarchic period (1 Sam 22:20-23; 2 Sam 15:24-37; 1 Kgs 2:26-27). As noted by Collins and Flint, "[ $\mathrm{t}]$ he inclusion of Abiathar shows that this list was not exclusively Zadokite." 28 The mention of the high priest "Hilkiah" in line 8 showcases an individual responsible for rediscovering the law in the temple and subsequently instrumental in Josiah's resulting religious reforms (2 Kgs 22:2-23:7) ${ }^{29}$

27 The Aramaic Levi Document traces the lines of the priesthood in moments of priestly appointment, transmission of tradition between generations, and in autobiographical interludes (ALD 8-13; 50-51; 57; 63-67). While Testament of Qahat does not include a formal list, its language of transmitting and safeguarding the tradition implies a similar model of teachings received from past generations of priests, not least traditions inherited from Jacob, Abraham, and Levi (4Q542 1 i 4-13) directed toward Amram (4Q541 1 ii 9-10). In a component of Amram's dream-vision an angelic revealer discloses the "mystery" (רז) of the priesthood to Amram, at least part of which seems to relate to seven generations of priests that have proceeded since its foundation with the patriarch Abraham (4Q545 4 13-19). I have argued elsewhere that the angelic revealer here is likely to be identified with a celestial Melchizedek figure and that association suggests the writer of Visions of Amram was drawing the earthly and heavenly priesthoods into closer proximity or continuity (Andrew B. Perrin, The Dynamics of Dream-Vision Revelation in the Aramaic Dead Sea Scrolls, JAJSup 19 [Göttingen: Vandenhoek \& Ruprecht, 2015], 166-70). See now also, Blake A. Jurgens, "Reassessing the Dream-Vision of the Vision of Amram (4Q543-547)," JSP 24 (2014): 3-42.

28 Collins and Flint, DJD 22:161.

29 Incidentally, one of the religious practices said to have been corrected in the aftermath of the discovery was the destruction of the site of child sacrifice in the valley of Hinnom (2 Kgs 23:10). A partial line of text in 4Q243 132 references "sacri]ficing their children to demons of" (דב] notation and the reference to Hilkiah in the genealogy above are related, since 4Q243 133 references the exile under Nebuchadnezzar. 
To this point, the scribal memory of Pseudo-Daniel spans from the priesthood's earliest existence to expressions in the time of Solomon's temple.

Lines 9-10, however, bridge memories of the priestly forefathers from the distant past to the more recent memory or, as we will see, ex eventu projections, of the priesthood in the Second Temple period. The name "Onias" in line 9 is understandably associated with the Oniad dynasty, yet is not easily narrowed to a single individual with that name. As VanderKam commented, in view of the text's fragmentary nature, we "cannot be sure which Onias is meant."30 From Josephus we learn that the first high priest named Onias held office in the time of Alexander the Great (Ant. 11.347). Following a few quick successions and shifts of power, his grandson, Onias II, is remembered by Josephus for gaining favor with the Ptolemies (Ant.12.158-159). Succeeding Simon II, the tenure of Onias III as high priest came at a time of turmoil in Jerusalem that eventually resulted in his removal by Antiochus IV. After his untimely death (cf. 2 Macc 4:34), his son Onias IV sought refuge in Egypt and was instrumental in founding the temple establishment of Heliopolis (Ant. 13.62-73). While ascertaining which Onias is in view for Pseudo-Daniel is something like picking out Kirk Douglas from a crowd of Spartacuses (Spartaci?), the very inclusion of the name plugs the genealogy into a tradition associated with a dynasty of priestly prominence during critical years of transition from Ptolemaic to Seleucid rule in Judaea. ${ }^{31}$

The final two priestly figures plausibly found in the text in line 11 also hail from the Hellenistic era, yet are of different dynastic stock. While the name "Jonathan" is evident only by ink traces of the final two characters, the reconstruction is highly likely given the fully retained name "Simon" that follows in the sequence. ${ }^{32}$ This pair then signals a priestly line associated with the Hasmoneans. While there are many interpretive and historical issues involved in triangulating the priestly tenure and royal claims or reigns of Hasmonean leaders, it seems that Jonathan is the first of the Hasmonean line to ascend to a position of priestly leadership. ${ }^{33}$ In this way, Pseudo-Daniel includes yet

30 James C. VanderKam, From Joshua to Caiaphas: High Priests after the Exile (Minneapolis, MN: Fortress; Assen: van Gorcum, 2004), 265. For a helpful survey of the emergence and existence of this priestly family, see Gideon Bohak, "Oniads," EDEJ, 1006-1007. While it is possible that the writer of the text understood the Oniads as in the heritage of the line of Zadok, this is not certain (Collins and Flint, DJD 22:161).

32 Collins and Flint, DJD 22:160.

33 Cf. 1 Macc 10:1-45; Ant. 13.39-57. For a full treatment of the problems inherent in the pertinent ancient sources and perspectives on triangulating them, see VanderKam, From Joshua to Caiaphas, 251-70. 
another figure associated with the founding or appointment of a priestly house (Jonathan) and his progeny (Simon).

While Simon is the final extant name of a priest in the line before the content picks up again with reference to kings from Israel's past, the mention of at least three priestly figures from the mid-Second Temple period is significant. If the name of Daniel at the outset of the fragment is taken to signal the narrative setting and key character of the work-it seems far less likely that Daniel was transported back in time into the ages of the genealogies-then this section of the genealogy shifts from retrospective to prospective. While the memory of all the priestly generations presented in the list is past tense from the perspective of the reader, from the narrative vantage point of our character Daniel, the generations following Hilkiah project into the narrative future. That is, the genealogy blends a memorial catalogue of past priests with an ex eventu prospectus of priestly lines to come. This merging of memories and their strategic projection in the narrative, therefore, adds to Daniel's characterization as it positions him as an authority for prognosticating the direction of the priesthood from past, present, and future. While "biblical" Daniel is no stranger to ex eventu prophecies of a political nature in light of empire and at times reflects on the polluting impact of empire on temple worship (Dan 9:27; 11:31; 12:11), the application of this mechanism to the leadership of the temple is not part of his profile as a sage or seer in that work.

\subsection{Remembering Monarchic Origins as Separate from Priestly Lines and Leadership}

As 4Q245 1 i narrows, lines 11-12 transition the genealogy into a list of names associated with the monarchy. The names "David" and "Solomon" are at or near a clear reset in the genealogy. It is possible that the list commenced with Saul at the end of line 10, yet this is speculative. The partially extant reading "Ahaziah" and the largely reconstructed reading "Joash" seem reasonable in light of their paired naming in the list of kings in $1 \mathrm{Chr} 3: 11 .{ }^{34}$ While much could be said of the inclusion of David and Solomon here, for the present purposes it is most significant that, not unlike what was observed for the priestly list, the scribe is interested in establishing memories of an institution through the monuments of its founding figures.

34 Collins and Flint, DJD 22:16o. In a preliminary edition, Flint (Peter W. Flint, "4QpseudoDaniel $\operatorname{arc}^{c}$ (4Q245) and the Restoration of the Priesthood," RevQ 17 [1996]: 137-50) included the reading "Mana]ss[eh" (מנ]שׁ[ה) in line 13, which was rightly omitted from the official publication. 
As was also the case with the priestly list, our Daniel is associated with yet another tradition-that of the monarchic age, including its earliest representatives - that has yet to figure in his characterization elsewhere in the tradition. ${ }^{35}$ While Daniel has an extensive resume in the service of foreign kings in the Hebrew Scriptures, Pseudo-Daniel's memory of iconic kings of Israel's own history draws him more closely to the monarchic past. This seems to have enabled the scribe to utilize the Daniel tradition as a space for comment on a more recent manifestation of Jewish monarchy.

Since it is evident that the list of priests is clearly set apart from that of the kings - the lists occur separately and there is no overlap between them in terms of content or chronology - this structural mechanism of the genealogy presents a memory of these institutions as at once jointly part of Israelite heritage and distinct in their origins and expression. This separation of offices and ex eventu presentation of the genealogies may have served a rhetorical purpose in the author's own past or present, in which the delineation or dual occupation of these positions was a contentious issue for some groups. As Flint observed, 4Q245 envisages "that in the divine plan priests and kings belong to separate groupings, and are not to be mingled even when they overlap chronologically."36 By ordering the memory of the institutions in this way, the genealogies likely make a prescription for the occupation and exercising of offices in the author's own day. Without a fuller knowledge of the compositional structure and social setting of $4 Q_{245}$, the particular target of this rhetoric cannot be sited with certainty.

\subsection{Textuality and Authority of Pseudo-Daniel's Genealogical Memories}

The reference to a "writing" (כתב) (4Q245 1 i 4) in advance of the genealogy suggests that the list that follows is accessed or disclosed from a document presented as a prop within the narrative. Since Daniel is mentioned at 4Q245 1 i 3 , he likely has some relation to the document and its transmission. 4Q243 6 ${ }^{2-3}$ includes yet another mention of booklore. ${ }^{37}$ However, the limited context available makes Daniel's association or interaction with it unknown. ${ }^{38}$

35 Given the fragmentary nature of the evidence, the relation of the reference to Daniel and the content that follows is not certain. Yet as argued below, it seems the link is perhaps via booklore read or received.

36 Flint, “4Qpseudo-Daniel $\operatorname{ar}^{c}$ (4Q245)," 142.

37 Whether this is related to $4 \mathrm{Q}_{245} 1 \mathrm{i} 4 \mathrm{is}$ uncertain.

38 John J. Collins, "Pseudo-Daniel," in Writings outside the Bible: Ancient Jewish Writings Related to Scripture, ed. Louis H. Feldman, James L. Kugel, and Lawrence H. Schiffman (Lincoln, NE: University of Nebraska Press/Jewish Publication Society, 2013), 614-19 (619), suggested that the phrase here in $4 \mathrm{Q}_{2} 43$ "is apparently [a reference] to a writing 
The portrayal of figures accessing, inscribing, or expounding knowledge gleaned from booklore is a common literary theme in the Aramaic Dead Sea Scrolls. In the biblical book, Daniel is no stranger to the scribal activities of reading and writing. Most often, these actions relate to his interpretive agency in unlocking cryptically inscribed omens, symbolic dream-visions, or interpretation of ancestral traditions (Dan 5:15-17; 7:1; 9:1-2; 12:4, 9).

4 Q245 associates Daniel with lore of a distinctly different nature. Daniel either pens or, more likely, accesses a veritable book of memories spanning the scope of ancestral to national histories and beyond. This retrospective encapsulates memories of Israel's most iconic institutions and offices of leadership. The content of this inscribed "writing" is certainly of political significance yet its focus is not overtly on empire. Rather, its religious-political nature is concerned with precise and detailed knowledge of institutions and individuals that were (or would become) actors in the more localized, internal history of the Jewish people. In the Hebrew Scriptures, Daniel's ex eventu outlooks and inscribed revelations establish him as an authoritative figure with revealed and reliable knowledge of imperial movements. In both "biblical" and Pseudo-Daniel, the writtenness of these prophecies underscores their certainty and accentuates the authority of the figure delivering them. ${ }^{39}$

Daniel's association with booklore takes on new significance in the larger context of the Aramaic Dead Sea Scrolls. The redrawn portraits of ancestors

that includes both past and future history." In view of the naming of Enoch in 4Q243 91 , he posited that the mention of booklore in Pseudo-Daniel could be of Enochic origin. DiTommaso ("4QPseudo-Daniel ${ }^{a-b}$," 128 ) argued that this Enochic origin is unlikely since Enoch's name "is mentioned in the portion of $4 \mathrm{Q} 243 / 244$ that contains the ex eventu review of history." However, since the name of Enoch is the only full and legible word on 4 Q243 9, the placement of this fragment in the composition cannot be determined with certainty. In view of the Arabic Malhamat Dāniyāl, which relates Daniel's retrieval of Adamic tablets from a hidden cave in Jerusalem, DiTommaso queried whether or not the booklore of Pseudo-Daniel was penned by Adam. He rightly noted, however, that "this very late connection ... is impossible to prove" ("4QPseudo-Daniela-b," 129-30). The means of access to this document is equally uncertain in the limited context. Collins and Flint (DJD 22:135) suggest that Daniel is the reader of this inscribed content. DiTommaso ("4QPseudo-Daniel ${ }^{a-b, " ~ 128) ~ n o t e d ~ t h a t, ~ "[w] h e t h e r ~ D a n i e l ~ a c t u a l l y ~ r e a d s ~ f r o m ~ t h e ~ w r i t-~}$ ing or interprets it is impossible to say." If the composition included some sort of revelatory encounter, the book in question would presumably fit either within the episode itself, plausibly disclosed by an otherworldly revealer, or would be a document penned by Daniel as a testimony to the content of the revelation.

39 On the symbolic significance and gradual rise of authority related to claims of writtenness in exilic and post-exilic literatures, see Hindy Najman, Past Renewals: Interpretive Authority, Renewed Revelation and the Quest for Perfection in Jewish Antiquity, JsJs 53 (Leiden: Brill, 2010), 3-38. 
regularly involved their transmission of booklore, performance of inscribed tradition, pseudepigraphic attribution, association with a book from the past, or various scribal actions of reading, penning, and hearing written materials. ${ }^{40}$ While we do not know the exact origins of the document in the narrative of $4 \mathrm{Q}_{245}$, as well as the reference to a "writing" in $4 \mathrm{Q}_{243} 62$, the audience encounters it presumably through the conduit of Daniel: he is cast as either a privileged reader or writer of the tradition, as one who remembers and projects. As noted above, since some components of this genealogy remembered were ex eventu, Daniel's prophetic prowess and authority in Pseudo-Daniel is compounded on account of his association with booklore.

\section{Allusions to Episodes from the Ancestral Past in the Imperial Present}

While the previous sections have solidified Daniel's association with memories of named individuals of the patriarchal and monarchic periods, combing the fragments of Pseudo-Daniel reveals that its memorial to the past includes many mentions of events and episodes culled from the primeval history or themes of the exodus traditions.

\subsection{Pseudo-Daniel's Recollection of the Deluge among Aramaic Memories of the Flood}

The primeval past looms large in 4 Q244 8. The phrase "from after the flood" (בת)) (בתר מבולא in line 2 signals a memory of the diluvian days of Genesis. The limited words that follow, however, indicate that Pseudo-Daniel's memory is cast in terms of broader Second Temple flood traditions. The location "Lubar" (לובר) in $4 Q_{244} 83$ features elsewhere in the Aramaic texts, in Genesis Apocryphon

40 On this phenomenon across the Aramaic corpus, see Richard C. Steiner, "The Heading of the 'Book of the Words of Noah' on a Fragment of the Genesis Apocryphon: New Light on a 'Lost' Work," DSD 2 (1995): 66-71; Henryk Drawnel, "The Initial Narrative of the Visions of Amram and Its Literary Characteristics," RevQ 24 (2010): 517-54; Andrew B. Perrin, "Capturing the Voices of Pseudepigraphic Personae: On the Form and Function of Incipits in the Aramaic Dead Sea Scrolls," DSD 20 (2013): 98-123; and Mladen Popović, "Pseudepigraphy and a Scribal Sense of the Past in the Ancient Mediterranean: A Copy of the Book of the Words of the Vision of Amram," in Is There a Text in this Cave? Studies in the Textuality of the Dead Sea Scrolls in Honour of George J. Brooke, ed. Ariel Feldman, Maria Cioată, and Charlotte Hempel, sTDJ 119 (Leiden: Brill, 2017), 308-18. These superscriptions may also be considered in light of Hebrew texts both at Qumran (War Scroll, 1QS, Pseudo-Ezekiel) and the Hebrew Scriptures (the Psalms) that couch content using titular features deploying the names of authoritative figures. 
(1QapGen 12:13) and Book of Giants (6Q8 26 1), as well as in Jub. 5:28 and 7:1. Jubilees cites Mount Lubar in the context of the founding of cities by Noah and his sons (7:17) as well as the location of Noah's burial (10:15). The mention of "a city" (קْריה) in 4Q244 84 may indicate an analogous tradition. In these ways, the terms of reference for this memory of the flood in Pseudo-Daniel are represented in particular concentration in Aramaic literature among the Qumran scrolls or writings in some relation to such traditions.

\subsection{The Tower of Babel}

Though fragmentary, 4Q243 10 seems to reference a Babel tradition (Gen 11:1-9).

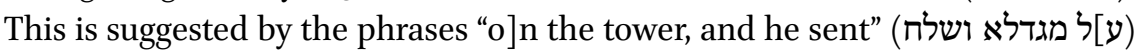

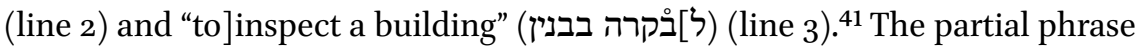
"the tower, [whose] heig[ht" (מגדלא רוֹ] 4Q 4Q244 92 may also relate to this scene. Kugel suggested that 4Q243 102 may be read in light of the phrasing "let us go down" in Gen 10:7, perhaps suggesting that the interpretation in Pseudo-Daniel implied God remained in heaven while dispatching heavenly emissaries to investigate the tower. ${ }^{42}$

\subsection{The Exodus as Heard through the Memory of Genesis}

The phrase "Egypt, by the hand of" (מצרין ביד) in 4Q243 11 ii 2 hints at an exodus tradition. 4Q243 12, however, includes the fullest representation of terms reminiscent of the exodus in Pseudo-Daniel:

1. fo]ur hundred [years,] and from (שנין אר]בבע מאה ומן)

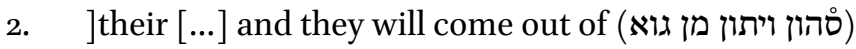

3. ] their crossing the Jordan, the $[x$ th $]$ jubilee 43 (מעברהון ירדנא יובל]א)

41 For comments on the likely association of these phrases with Gen 11:4-5, see Florentino García Martínez, Qumran and Apocalyptic: Studies on the Aramaic Texts from Qumran, STDJ 9 (Leiden: Brill, 1992), 141; and Collins and Flint, DJD 22:104.

42 James L. Kugel, Traditions of the Bible: A Guide to the Bible As It Was at the Start of the Common Era (Cambridge, MA: Harvard University Press, 1998), 242. In translation, Cook seems to have rendered and reconstructed in view of such an understanding: "agai]nst the tower and He sent [angels" (Michael O. Wise, Martin G. Abegg, and Edward M. Cook, The Dead Sea Scrolls: A New Translation [New York: HarperSanFrancisco, 2005], 343). Note that in Gen 11:5, however, the statement about descending and viewing the city and the tower is in the singular.

43 Collins and Flint (DJD 22:105) rendered this line as "their crossing the rive[r] Jordan." García Martínez (Qumran and Apocalyptic, 141-42) previously concluded that given the nearby reference to the "Jordan" (ירדנא), the term יובל]א should be understood as the "river Jordan". At the time, he indicated the meaning "jubilee" was unknown in ancient Jewish Aramaic literature. However, it is now evident that the term occurs in 1QapGen 6:10 with this meaning. Furthermore, while there is indeed precedent in Hebrew literature for the terms יָָָ ("watercourse") (Is 30:25; 44:4; Job 20:28), יוּבַל ("canal" or "stream") (Jer 17:8; 
4. ] ] דבניהון)

5. ]... [ (דיתi)

This fragment not only closely relates the exodus with the memory of the wanderings and entering the land (see next), it sets the recollection of Egypt in a chronological framework indicating duration of captivity. The reference to 400 years seems to represent the prediction of Egyptian bondage presented to Abram in Gen 15:13, not the figure of 430 years as found in Exod 12:40-41. García Martínez noted that Jubilees deploys both figures in chronologies (cf. Jub. 16:13; 50:4) yet Pseudo-Daniel parallels the estimations of Philo (Heir 54) and Josephus (Ant. 2.8.2; J.W. 5.9.4; cf. Ant. 2.15.2), who both remembered the period of Egyptian captivity as 400 years. ${ }^{44}$ The conspicuous connection of the figure 400 with Gen 15:13 increases the likelihood that Abraham was one of the ancestors included elsewhere in the lost Pseudo-Daniel text. ${ }^{45}$

\subsection{The Wilderness Period}

Pseudo-Daniel includes scattered references to items related to the wanderings and entry into the land. While nothing survives around the word in question, 4Q243 341 reads simply "from the tabernacle" (מן משכנא). This mention introduces yet another important priestly institution from the past. The term משכן referring to the tent of meeting is found in the Cave 4 Aramaic Leviticus translation (4Q156 24 [cf. MT אה מקל at Lev 16:20]) as well as in the fragmentary remains of the Enochic "Animal Apocalypse." In the latter, the reading מُ]כ is minimally preserved yet comes in the context of Moses founding the tent (4Q204 410 [1 En. 89:36]). In view of the interest in ancestral figures, it is possible that the mention of the "tabernacle" suggests the presence of Moses in some way.

1QH 8:7, 10), or אִב ("canal") (Dan 8:2), nowhere is the Jordan river described in such geographical terms. НALOT lists the present instance of the term in Pseudo-Daniel as meaning "water-course" or "canal" on the recommendation of Milik (Józef T. Milik, "Prière de Nabonide' et autres écrits d'un cycle de Daniel," $R B 63$ [1956]: 407-15, esp. 412). Beyer read and rendered along similar lines: ויבל ("und den Bach") (Klaus Beyer, Die aramäischen Texte vom Toten Meer samt den Inschriften aus Palästina, dem Testament Levis aus der Kairoer Genisa, der Fastenrolle und den alten talmudischen Zitaten: Band II [Göttingen: Vandenhoeck \& Ruprecht, 2004], 140-41). However, this understanding should now be corrected to the gloss "jubilee year," as suggested here and listed appropriately by Cook (Edward M. Cook, Dictionary of Qumran Aramaic [Winona Lake, IN: Eisenbrauns, 2015], 101). See also his translation of the passage along these lines in Wise, Abegg, and Cook,

The Dead Sea Scrolls, 343 .

44 García Martínez, Qumran and Apocalyptic, 141.

45 Recall the mention of "the Chaldeans" (כשדיא) in 4Q243 72. 
As indicated in the text cited in the previous section, 4Q243 123 references the crossing of the Jordan. By virtue of the partially extant reading יובלאי, this mention is set in some jubilean chronology. While not easily coordinated with any particular tradition in the Hebrew Scriptures referencing the fording of the Jordan, given that this phrase in 4 Q243 123 follows content relating the exodus and Egyptian captivity, Pseudo-Daniel likely broached the entrance into the promised land in some way. \\ References to Babylonian, Assyrian, and Hellenistic Imperial Rulers}

The bulk of this study has explored Pseudo-Daniel's integration of episodes and actors from the ancestral past and Israel's national history. The fragments also include mentions of persons and places from the imperial contexts of the exilic and post-exilic periods.

Given the plausible narrative setting of Pseudo-Daniel in a foreign court context, references to "Nebuchadnezzar" (4Q243 23 2) and "Balshazzar" (בלשצْ) (4Q243 2 2) are perhaps not surprising. 4Q243 13 3, however, reads "to

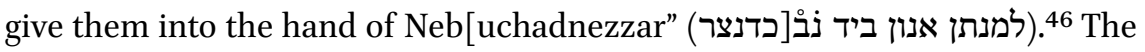
nature of this phrasing suggests that the reference to Nebuchadnezzar is within the historical review. ${ }^{47}$ As DiTommaso noted, the reference to Balshazzar may indicate the narrative setting of this unit or the work. ${ }^{48}$ At a minimum, these references to Babylonian kings in Pseudo-Daniel are associated with memories of the exile.

46 The phrasing of 4Q243 133 resembles an important component of Qumran sectarian memory regarding the survival of a remnant in the opening column of the Damascus Document. CD 1:6 relates that after 390 years God "gave them into the hand of Nebuchadnezzar, King of Babylon” (לתיתו אותם ביד נבוכדנאצר מלך בבל). For general comments on this parallel, see Collins, "Pseudo-Daniel Revisited," 128; and Collins and Flint, DJD 22:137. Note also that this language in both texts seems to be informed by a use of Ps 104:41 (40) (Armin Lange and Matthias Weigold, Biblical Quotations and Allusions in Second Temple Jewish Literature, JAJSup 5 [Göttingen: Vandenhoeck \& Ruprecht, 2011], 174). However, CD and Pseudo-Daniel share a secondary development, exchanging the generic "hand of the nations" (ביד גוים) in the biblical text for the more specific "hand of Nebuchadnezzar." While the question of the relevance of the book of Daniel to sectarian memory, historiography, and identity has been broached preliminarily, Hempel is correct that this angle on community origins must also take into consideration the broader set of now-known Danielic traditions and their potentially broader social settings (Charlotte Hempel, "The Community Rule and the Book of Daniel," in The Qumran Rule Texts in Context: Collected Studies, TSAJ 154 [Tübingen: Mohr Siebeck, 2013], 231-52).

47 Note this placement in Collins and Flint's reconstruction (DJD 22:147-48).

48 DiTommaso, “4QPseudo-Daniel ${ }^{a-b, "} 111$. 
The view of imperial history in Pseudo-Daniel, however, extends in both directions from the narrative present. Daniel is associated with memories of antecedent empires as well as ex eventu content seemingly projecting geopolitical movements in the narrative's future and the audience's recent past. On the one hand, we find a retrospective reference to "Before the nobles of the king and the Assyrians" (קודם רברבני מלכא ואשיאריא) in 4Q244 1-3 1.49 On the other hand, 4Q243 212 includes reference to one "Balakros" (בלכרוס). As Collins highlighted, three of Alexander the Great's officers went by this name. ${ }^{50}$ The inclusion of this name, therefore, registers the Hellenistic period in the memory and historiography of Pseudo-Daniel. It is possible that additional figures associated with the Hellenistic or Roman empires are named in 4Q243 19 1-2; however, since only the endings of two names have survived ( רזיסוס[?]), these cannot be identified with certainty. ${ }^{51}$ In view of these few references, García Martínez concluded that "despite the fact that the personages in question must retain their anonymity and remain wrapped in mystery, the mere circumstance of their mention by name is quite interesting, and differentiates our texts from other mss. of Qumran, in which allusions of an actual historical character are extremely rare."52 I would add that this quality in Pseudo-Daniel also sets the Aramaic work apart from "biblical" Daniel, since the latter veils its critiques of empires and pagan kings in symbolic dream-visions and ciphers.

This study treated only aspects of the often complex and challenging fragments of Pseudo-Daniel. Nonetheless, the discussion above has implications

49 For other paired references to kings and nobility in Jewish Aramaic literature, see Dan 5:23; 1QapGen 19:24; and 4Q550 5 + 5a 3 .

50 Collins, "Pseudo-Daniel Revisited," 128; cf. the discussion in García Martínez, Qumran and Apocalyptic, 144-45. Mentions of this name in classical sources include: Diodorus Sciulus 17.57; 18.22; Arrian, Anabasis 1.29.3; 2.12.2; 3.5.5; 3.12.3; 4.4.6; 24.10. Both Collins and García Martínez rightly critiqued Milik's forced attempt to identify Balakros with Alexander Balas (Milik, "Prière de Nabonide," 415).

$5^{1}$ While there is no consensus on the full names in view here, Milik proposed "Demetrius" (Milik, "Prière de Nabonide," 414, n. 2), Puech suggested "Darius" (Émile Puech, La croyance des Esseniens en la vie future: immortalité, résurrection, vie éternelle? Histoire d'une croyance dans le judaïsme ancien, EBib 21-22 [Paris: Gabalda, 1993], 568), and Collins briefly considered "Pyrrhus of Epirus," though he remarked that "[i]t is difficult to imagine why Pyrrhus should be mentioned in a Jewish apocalyptic text ... Ultimately, any reconstruction of the name is only a guess" (Collins, "Pseudo-Daniel Revisited," 119). García Martínez, Qumran and Apocalyptic, 145. 
for the question of Daniel's broader profile in ancient Jewish literature as well as for our understanding of Danielic traditions within the Aramaic Dead Sea Scrolls corpus.

\subsection{Remembering as a Creative Process for Character Development and Tradition Formation}

The threefold use of the curious turn of phrase that it was "this Daniel" (MT who escaped unscathed from the lion's den is a literary device for emphatically drawing attention to the persona at the heart of that dramatic episode (Dan 6:4, 6, 29). Rhetorically, we might ask: Is "this" Daniel in the biblical book the same as "that" Daniel encountered in Pseudo-Daniel? Yes and no.

To use the analogy of scenes, characters, and storyboards, it seems safe to say that in Aramaic Pseudo-Daniel—or any other representatives of the Danielic tradition in ancient Judaism - we are dealing with the same actor known from the "biblical" book, yet we are seeing him in a different performance setting where he is drawn differently. The contributors to this rapidly developing tradition in the centuries leading up to the Common Era seem to have cast Daniel in several scenes and stories and, therefore, cultivated a dynamic persona for the figure that worked itself out differently in different narrative settings. As a character, Daniel is bigger than any one text or performance. To push the analogy further, his performance in what became the "biblical" book won the accolade of a canonical position; however, it does not follow that this subsequent reception indicates the priority of this work in early formation of the broader Daniel tradition.

In the case of Pseudo-Daniel, at least part of Daniel's characterization was enabled or enhanced by an ambitious scribal attempt to foreground Daniel against a backdrop of curated memories of individuals, episodes, and eras from Israel's past. In many instances, the presentation of these memories included ancestral figures (Noah and Enoch), individuals foundational to the origins of the monarchy (David and Solomon) and historic priesthoods (Levi, Zadok, and Abiathar), as well as reference to essential parts of Israel's collective memory (the flood, exodus, and exiles). While our Daniel in Pseudo-Daniel remains a figure plausibly set in the Babylonian period, these memories of the past enhance his profile as a reliable conduit for delivering retrospective views of Israelite experience and prospective (or even prescriptive) outlooks for Jewish identity in the contemporary world of the scribe and audience.

The evidence that the Pseudo-Daniel materials assume or require a reference point in "biblical" Daniel is limited, or at a minimum, an area in need of further study. Therefore, what is at the core of the tradition at this early stage is a character, not a particular text within that tradition. While the book of 
Daniel became popular in and beyond Qumran shortly after its composition in the mid-second century вСЕ, I would argue that the status of the book is in many ways indebted to the stature of the character within it. This stature was achieved in part by his elevated profile developed across the tradition, which was initiated and cultivated in ancient Jewish Aramaic scribal settings. While we find a significant mention of Daniel in Florilegium, it is intriguing that the phrase "whi]ch was written in the writing of Daniel the prophet" (אש] רתוב בספר דניאל הנביא) (4Q174 1-3 ii 3) both associates this figure with some authoritative inscribed tradition as well as underscores the prophetic persona behind it.

\subsection{Implications for Articulating the Contours and Categories of the Aramaic Dead Sea Scrolls Corpus}

As is widely recognized in current scholarship on the Qumran Aramaic texts, these writings are generally oriented around either the antediluvian/ancestral past or the exilic age..$^{53}$ This observation certainly accounts for the predominant compositional and narrative settings across the corpus. On literary grounds, Pseudo-Daniel is no exception: Daniel again finds himself on the payroll of the Babylonian court. However, in terms of the content of the materials associated with the persona of Daniel in this exilic context, the majority of eras, episodes, and individuals included in the fragmentary remains were memories from the ancestral and national pasts. Pseudo-Daniel's recollections effectively straddled both the predominant settings of the Aramaic texts. While the work was set in the recent exilic past, a significant amount of its content and concerns were anchored in the more antiquated ancestral past, not least traditions from Genesis.

Furthermore, the work traversed the territory and times between these ages. The genealogical traditions described above perhaps best illustrate this point. This vehicle of memory included references to founding figures and lines initiated in Genesis, acknowledged the heads of multiple priestly families of

53 For comment on these predominant narrative settings, see Devorah Dimant, "Themes and Genres in the Aramaic Texts from Qumran," in Aramaica Qumranica: Proceedings of the Conference on the Aramaic Texts from Qumran in Aix-en-Provence, 30 June-2July 2008, ed. Katell Berthelot and Daniel Stökl Ben Ezra, STDJ 94 (Leiden: Brill, 2010), 15-45; Eibert J. C. Tigchelaar, "Aramaic Texts from Qumran and the Authoritativeness of Hebrew Scriptures: Preliminary Observations," in Authoritative Scriptures in Ancient Judaism, ed. Mladen Popović, JSJS 141 (Leiden: Brill, 2010), 155-71; and Florentino García Martínez, "Les rapports avec l'Écriture des textes araméenes trouvés à Qumran," in Old Testament Pseudepigrapha and the Scriptures, ed. Eibert J. C. Tigchelaar, BETL 270 (Leuven: Peeters, 2014), 19-40. 
the monarchic period, and eventually named high priests that extended into the Second Temple period. ${ }^{54}$ The mention of royal figures-not least David and Solomon-established a space for remembering the united monarchy of Israel. While Pseudo-Daniel's narrative is related in retrospect from the eastern diaspora, the coverage of its memories was not limited to the poles of Israelite history. Rather, their trajectories originated in the ancestral past, set explicit signposts throughout Israelite history, and terminated in the eschatological future.

\section{Bibliography}

Assmann, Jan. Moses the Egyptian: The Memory of Egypt in Western Monotheism. Cambridge, MA: Harvard University Press, 1998.

Assmann, Jan. Religion and Cultural Memory: Ten Studies. Translated by Rodney Livingstone. Stanford, CA: Stanford University Press, 2006.

Beyer, Klaus. Die aramäischen Texte vom Toten Meer samt den Inschriften aus Palästina, dem Testament Levis aus der Kairoer Genisa, der Fastenrolle und den alten talmudischen Zitaten: Band II. Göttingen: Vandenhoeck \& Ruprecht, 2004.

Bohak, Gideon. “Oniads." Pages 1006-1007 in The Eerdmans Dictionary of Early Judaism. Edited by John J. Collins and Daniel C. Harlow. Grand Rapids, MI: Eerdmans, 2010.

Brooke, George J. "Memory, Cultural Memory and Rewriting Scripture." Pages 119-36 in Rewritten Bible after Fifty Years: Texts, Terms, or Techniques? A Last Dialogue with Geza Vermes. Edited by József Zsengellér. JsJs 166. Leiden: Brill, 2014.

Bruce, Frederick F. "Josephus and Daniel." Pages 19-31 in A Mind for What Matters: Collected Essays of F. F. Bruce. Grand Rapids, MI: Eerdmans, 1990.

Campbell, Jonathan G. "Rewritten Bible: A Terminological Reassessment." Pages 49-81 in Rewritten Bible after Fifty Years: Texts, Terms, or Techniques? A Last Dialogue with Geza Vermes. Edited by József Zsengellér. JsJs 166. Leiden: Brill, 2014.

Collins, John J. “Pseudo-Daniel Revisited." RevQ 17 (1996): 111-35.

Collins, John J. "Pseudo-Daniel." Pages 614-19 in Writings outside the Bible: Ancient Jewish Writings Related to Scripture. Edited by Louis H. Feldman, James L. Kugel,

54 Pseudo-Daniel includes more non-ciphered references to individuals, events, and institutions related to history proper than any other writing in the Qumran Aramaic corpus. Second to Pseudo-Daniel is the not easily understood scattered references to the "kingdom of Uzziah" (מלכות עוזיה), "Elijah" (אליה), and "Elisha" (אליש[ע) in the highly fragmentary text of 4 QpapVision ${ }^{\mathrm{b}}$ (4Q558 29 4; 51 ii 4; 62 2). The Enochic "Animal Apocalypse" should also register in the conversation, as this text is clearly set in the antediluvian age yet includes memories shrouded in symbolic ciphers of a large sweep of Israelite history, including content from Israel's national history (cf. 1 En. 89:39-58). 
and Lawrence H. Schiffman. Lincoln, NE: University of Nebraska Press/Jewish Publication Society, 2013.

Collins, John J., and PeterW. Flint. "Pseudo-Daniel." Pages 95-164 in Qumran Cave 4.XVII: Parabiblical Texts, Part 3 . Edited by George J. Brooke, John J. Collins, Peter W. Flint, Jonas Greenfield, Erik Larson, Carol Newsom, Émile Puech, Lawrence H. Schiffman, Michael Stone, and Julio Trebolle Barrera in consultation with James Vanderkam. DJD 22. Oxford: Clarendon Press, 1996.

Cook, Edward M. Dictionary of Qumran Aramaic. Winona Lake, IN: Eisenbrauns, 2015.

Davies, Philip R. "What History Can We Get from the Scrolls, and How?" Pages 31-46 in The Dead Sea Scrolls: Texts and Context. Edited by Charlotte Hempel. STDJ 90. Leiden: Brill, 2010.

Dimant, Devorah. "Themes and Genres in the Aramaic Texts from Qumran." Pages 15-45 in Aramaica Qumranica: Proceedings of the Conference on the Aramaic Texts from Qumran in Aix-en Provence, 3oJune-2 July 2008. Edited by Katell Berthelot and Daniel Stökl Ben Ezra. ST DJ 94. Leiden: Brill, 2010.

DiTommaso, Lorenzo. “4QPseudo-Daniel ${ }^{a-b}\left(4 \mathrm{Q} 243^{-244)}\right.$ and the Book of Daniel." DSD 12 (2005): 101-33.

Drawnel, Henryk. "The Initial Narrative of the Visions of Amram and Its Literary Characteristics." RevQ 24 (2010): 517-554.

Flint, Peter W. "4Qpseudo-Daniel arc (4Q245) and the Restoration of the Priesthood." $\operatorname{RevQ} 17$ (1996): 137-50.

Fröhlich, Ida. "Babyloniaca from Qumran-Mesopotamian Lore in Qumran Aramaic Texts." Pages 577-6o1 in Studies in Economic and Social History of the Ancient Near East in Memory of Péter Vargyas. Edited by Zoltán Csabai. Ancient Near Eastern and Mediterranean Studies 2. Budapest: Hungarian Society for Ancient Studies, 2014.

García Martínez, Florentino. Qumran and Apocalyptic: Studies on the Aramaic Texts from Qumran. STDJ 9. Leiden: Brill, 1992.

García Martínez, Florentino. "Les rapports avec l'Écriture des textes araméenes trouvés à Qumran." Pages 19-40 in Old Testament Pseudepigrapha and the Scriptures. Edited by Eibert J. C. Tigchelaar. B ETL 270. Leuven: Peeters, 2014.

Gertz, Jan C., Bernard M. Levinson, Dalit Rom-Shiloni, and Konrad Schmid, eds. The Formation of the Pentateuch: Bridging the Academic Cultures of Europe, Israel, and North America. FAT 111. Tübingen: Mohr Siebeck, 2016.

Goff, Matthew J. "Gilgamesh the Giant: The Qumran Book of Giants' Appropriation of Gilgamesh Motifs." DSD 16 (2009): 221-53.

Grossman, Maxine L. Reading for History in the Damascus Document: A Methodological Study. STDJ 45. Leiden: Brill, 2002.

Hallo, William W., ed. Canonical Compositions of the Biblical World. Vol. 1 of The Context of Scripture. Leiden: Brill, 1997. 
Hempel, Charlotte. "The Community Rule and the Book of Daniel." Pages $231-52$ in The Qumran Rule Texts in Context: Collected Studies. TSAJ 154. Tübingen: Mohr Siebeck, 2013.

Humphreys, Lee W. "A Life-Style for the Diaspora: A Study of the Tales of Esther and Daniel." JBL 92 (1973): 211-23.

Jurgens, Blake A. "Reassessing the Dream-Vision of the Vision of Amram (4Q543-547)." JSP 24 (2014): 3-42.

Kugel, James L. Traditions of the Bible: A Guide to the Bible As It Was at the Start of the Common Era. Cambridge, MA: Harvard University Press, 1998.

Lange, Armin, and Matthias Weigold. Biblical Quotations and Allusions in Second Temple Jewish Literature. JAJSup 5. Göttingen: Vandenhoeck \& Ruprecht, 2011.

Machiela, Daniel A. "Once More, with Feeling: Rewritten Scripture in Ancient Judaism-A Review of Recent Developments." JJs 61 (2010): 308-20.

Milik, Józef T. “'Prière de Nabonide' et autres écrits d'un cycle de Daniel.” RB 63 (1956): 407-15.

Najman, Hindy. Seconding Sinai: The Development of Mosaic Discourse in Second Temple Judaism. JsJs 77. Leiden: Brill, 2003.

Najman, Hindy. Past Renewals: Interpretive Authority, Renewed Revelation and the Quest for Perfection in Jewish Antiquity. JsJs 53. Leiden: Brill, 2010.

Moore, Carey A. Tobit. AB. New Haven: Yale University Press, 1996.

Newsom, Carol A. "Why Nabonidus? Excavating Traditions from Qumran, the Hebrew Bible, and Neo-Babylonian Sources." Pages 57-79 in The Dead Sea Scrolls: Transmission of Traditions and Production of Texts. Edited by Sarianna Metso, Hindy Najman, and Eileen Schuller. STDJ 92. Leiden: Brill, 2010.

Olick, Jeffrey K., and Joyce Robbins. “Social Memory Studies: From 'Collective Memory' to the Historical Sociology of Mnemonic Practices." Annual Review of Sociology 24 (1998): 105-40.

Perrin, Andrew B. "Capturing the Voices of Pseudepigraphic Personae: On the Form and Function of Incipits in the Aramaic Dead Sea Scrolls." DSD 20 (2013): 98-123.

Perrin, Andrew B. The Dynamics of Dream-Vision Revelation in the Aramaic Dead Sea Scrolls. JAJSup19. Göttingen: Vandenhoeck \& Ruprecht, 2015.

Popović, Mladen. "Pseudepigraphy and a Scribal Sense of the Past in the Ancient Mediterranean: A Copy of the Book of the Words of the Vision of Amram." Pages 308-18 in Is There a Text in this Cave? Studies in the Textuality of the Dead Sea Scrolls in Honour of George J. Brooke. Edited by Ariel Feldman, Maria Cioată, and Charlotte Hempel. STDJ 119. Leiden: Brill, 2017.

Puech, Émile. La croyance des Esseniens en la vie future: immortalité, résurrection, vie éternelle? Histoire d'une croyance dans le judaïsme ancien. EBib 21-22. Paris: Gabalda, 1993. 
Roediger, Henry L., III, and James V. Wertsch. "Creating a New Discipline of Memory Studies." Memory Studies 1 (2008): 9-22.

Schwartz, Barry. "Where There's Smoke, There's Fire: Memory and History." Pages 7-37 in Memory and Identity in Ancient Judaism and Early Christianity: A Conversation with Barry Schwartz. Edited by Tom Thatcher. SemeiaSt 78. Atlanta: SB L Press, 2014.

Segal, Michael. Dreams, Riddles, and Visions: Textual, Contextual, and Intertextual Approaches to the Book of Daniel. BZAW 455. Berlin: de Gruyter, 2016.

Steiner, Richard C. 'The Heading of the 'Book of the Words of Noah' on a Fragment of the Genesis Apocryphon: New Light on a 'Lost' Work." DSD 2 (1995): 66-71.

Stock, Brian. The Implications of Literacy: Written Language and Models of Interpretation in the Eleventh and Twelfth Centuries. Princeton: Princeton University Press, 1983.

Tigchelaar, Eibert J. C. "Aramaic Texts from Qumran and the Authoritativeness of Hebrew Scriptures: Preliminary Observations." Pages $155^{-71}$ in Authoritative Scriptures in Ancient Judaism." Edited by Mladen Popović. JSJS 141. Leiden: Brill, 2010.

VanderKam, James C. From Joshua to Caiaphas: High Priests after the Exile. Minneapolis, MN: Fortress; Assen: van Gorcum, 2004.

Vermes, Géza. “Josephus' Treatment of the Book of Daniel.” JJS 42 (1991): 149-66.

Wise, Michael O. "4Q245 (PsDanc ar) and the High Priesthood of Judas Maccabaeus." DSD 12 (2005): 313-62.

Wise, Michael O., Martin G. Abegg, and Edward M. Cook. The Dead Sea Scrolls: A New Translation. New York: HarperSanFrancisco, 2005.

Zahn, Molly M. “Genre and Rewritten Scripture: A Reassessment." JBL 131 (2012):271-88. 